J. Jpn. Bronchoesophagol. Soc.

日気食会報，47（2）, 1996

Vol. 47 No. 2

pp. $63-69$

特 別 講 演

\title{
チーム医療による腫瘍の治療
}

平野実

\section{Team Practice in Treating Cancer Patients}

\author{
Minoru Hirano, M.D. \\ Department of Otolaryngology-Head and Neck Surgery, \\ Kurume University School of Medicine, Kurume
}

\begin{abstract}
Since 1989 we have been employing a team practice in treating patients with head and neck cancer. The team for laryngeal cancer consists of otolaryngologists and radiologists and that for hypopharyngeal cancer consists of otolaryngologists, radiologists, plastic surgeons and gastrointestinal surgeons. The team members see patients and examine test results together, determine treatment plans together, and conduct surgeries and follow-ups together.

A total of 187 patients with laryngeal cancer have been treated by our team during the past six years. Of these 187,146 had glottic and 41 had supraglottic lesions. The 5-year survival rate was 82.7 percent for all patients, and the disease-specific 5-year survival rate was 96.7 percent. Thirty-two patients with advanced hypopharyngeal cancer were treated with laryngopharyngoesophagectomy, bilateral neck and paratracheal dissection and thyroidectomy followed by reconstruction with the use of a free jejunum graft. Postoperative radiotherapy was employed. The 5-year survival rate was 54.4 percent for all cases and the disease specific 5 -year survival rate was 67.5 percent.
\end{abstract}

Key words : チーム医療, 喉頭癌, 下咽頭癌, 甲状腺癌

日本の病院における医療システムは, 診療側 の都合に合わせている面が多い。久留米大学病 院もその例に漏れないが, 1991年から様子が変 わりつつある。

\section{I ．久留米大学病院リニューアル計画}

1991年に始まった。完成までに約10年を要す る計画である。私は1991年 4 月から 4 年間, 病 院長としてこの計画を進めてきた。本計画には 3 つの柱がある。

久留米大学医学部耳鼻咽喉科

別刷請求： $\mathbf{T} 830$ 福岡県久留米市旭町 67

久留米大学医学部耳鼻咽喉科 平野 実

\section{1. 総合診療棟の建築}

外来, 中央検査と画像診断部門, 薬剂部, 手 術部, 材料室, 外科・脳外科病棟を含む 8 階建 て, 延べ約 $3,900 \mathrm{~m}^{2}$ の建築をする。土地購入, 設計, 許可手続きが終わり1995年11月に着工, 1998年に完成予定である。

\section{2. 診療システムの改革}

患者にとってより良いシステムにする，個々 の患者に病院が提供できる最高の医療を行う， また患者の移動距離や待ち時間を少なくするよ うにした。その目玉は総合外来方式，センター 方式, チーム医療である。

従来外来は講座単位で第一, 第二, 第三, 第 
表 1 外来の構成

\begin{tabular}{|c|c|}
\hline \multicolumn{2}{|c|}{ 旧（1992.5.まで）＼cjkstart現（1992.6.から） } \\
\hline 第一内科外来 & 消化器病センター \\
\hline 第二内科 $I 1$ & 循環器病センター \\
\hline 第三内科 $川$ & 呼吸器病センター \\
\hline 第四内科 & 内科総合外来 \\
\hline 放射線科 $" 1$ & （糖尿病，内分泌，血液，神経， \\
\hline 第一外科 $" 1$ & 腎，膠原病，放射線治療，一般) \\
\hline 第二外科 $\prime \prime$ & 外科総合外来 \\
\hline 小児外科 $" 1$ & （乳腺，小児，一般） \\
\hline
\end{tabular}

四内科，放射線科，第一，第二外科，それに診 療科の小児外科という構成であった。それをセ ンターと総合外来方式に改めた(表 1 )。患者が 多い消化器, 循環器, 呼吸器についてはセン夕 一を設置し, 内科, 外科, 放射線科の専門家が 同じ場所で診療するようにした。他の疾患につ いては, 内科, 外科総合外来で, 蔵器別の専門 外来を設けた。

医学部の講座は教育, 研究のための組織とし てあり, 各外来部門の医師の割り当てや派遣日 を関連講座が相談して決める。耳鼻咽喉科など 講座と診療科が同じ組織のところは, 後述のよ うなチーム医療を行っている。

病棟は建物の都合で講座別病棟のままである が, 総合診療棟が完成したあかつきには, 再編 成して内科病棟と外科病棟とし, その中で藏器 別に病室を配分する。チーム医療は入院患者に 対してもすでに行われており，第一外科と第二 外科の医師が,一緒に同じ患者を手術すること もある。

\section{3. 患者に対する親切キャンペーン}

1991年に始まった。病院長が旗を振るのでは なく, 若手の医師, ナース・薬剤師・検査技師 などのコメディカル・スタッフ, 事務職員など 約50名のチームが企画立案した。病院の全教職 員を動員し, 挨拶のしかた, 電話での応対, 案 内のしかた, 患者や家族への話し方, 接遇のし かたなどを改善しつつある。成果を自己点検・ 評価しながら, 次の活動を進めている。1994年 には, マニュアルを印刷刊行し, 全職員に配布 して親切な対応の普及につとめている。

\section{II . 耳身咽喉科・頭頊部外科のチーム医療}

病院全体に先駆けて始まった。1971年に私が 教授に就任したとき，これからはチーム医療の 時代になると思い, 関連ある科の教授に相談し た。しかし当時は，ほとんどの科が応じられな かった。私は最年少の教授であり，他科の世代 交代を待つことにした。ただ甲状腺内科の教授 が賛同され，連係診療を始めた。

1984年に形成外科が設置され，田井良明教授 を迎えてチーム医療を始めた。癌の広範切除と 皮弁や筋皮弁による一期的再建, 頭蓋底手術, 咽喉頭部分切除と一期的再建などが始まった。 以後次第に他の科も参加し，1989年には必要な 科が参加した頭頸部チームができた。耳鼻咽喉 科, 形成外科, 脳外科, 眼科, 口腔外科, 胸部 外科, 消化器外科, 血管外科, 放射線科, 内分 泌内科, 血液内科, 麻酔科, 病理が, 病例ごと に適切なチームを組み, 協同して診療している。 教育関連病院である聖マリア病院の耳鼻咽喉 科，放射線治療部もチームに加わった。

チーム医療は，異なる専門家を揃えただけで はできない。ある科で患者を診て, 紹介状を書 いて他の科へ廻す，それぞれの科で診て，返事 をもどす，というのが図 1 左であり，これはチ 一ム医療ではない。

図 1 右は 4 つの科の interaction があるチー 么医療を示す。 4 科の医師が患者を一緒に診る, 検査所見を一緒にみて討論する，治療計画を相 談して定めそれぞれの役割を決める，一緒に手 術をする，一緒に follow up し問題がおこれば 相談して対処する，というのがチーム医療であ る。

放射線科と耳鼻咽喉科とは，とくに緊密に連

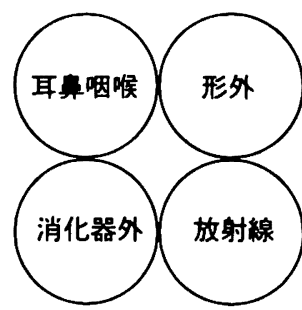

チーム医療ではない

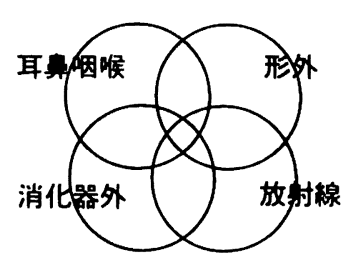

チーム医療
図 1 チーム医療の模式図 
係している。毎週 2 回, 治療前の入院患者につ いてカンファレンスを行い, 検査資料を検討し て治療方針を相談する。治療中の患者は毎週 2 回共同で回診し，必要があれば治療方針を修正 する。観察にはビデオファイバースコープを用 いる。退院後の患者は, 毎週 2 日の共診日に一 緒に follow up する。

下咽頭癌の患者については形成外科, 消化器 外科, 放射線科, 耳鼻咽喉科が, 頭蓋底手術で は脳外科, 形成外科, 放射線科, 耳鼻咽喉科が チームを組む。

また, 病理組織カンファレンスを毎週 1 回行 い, 関係者が集まって生検や手術標本を一緒に みて検討し, 治療法の追加, 変更なども相談す る。

\section{III．喉頭癌に対するチーム医療}

ファイバースコピーとストロボファイバース コピーのビデオ, 喉頭・頸部の CT, MRI, 頸部 触診所見を主な資料とし, 耳鼻咽喉科と放射線 科で治療方針を討議する。さらに患者や家族に 説明し，その希望も勘案して初治療を選ぶ。主 に考慮するのは制御率, 治療後の声, 合併症と 後遺症, 治療期間である。

\section{1. 声門癌}

1) 声門癌 Tis, Tla

制御率 $100 \%$ を最終目標とし,検討や反省を繰 り返しながら，取り組んでいる。
病変が粘膜固有層浅層に限局している場合に は, マイクロサージャリ下の excision biopsy を選ぶ。声帯䩗帯が露出するか, しないかとい う深さまで除去する(図 $2 \mathrm{~A}$ )。以前はレーザー を用いたが，取り過ぎになり勝ちで，また病理 組織検查を行いにくいので, 最近はメスと鋏で 切除し，そのあとレーザーで浅く蒸散している。

この時期の癌は上皮過形成, 異形成と臨床的 鑑別がむずかしいが, 治療法は同じであるから， 組織診断はあとでも構わない。制御率と治療後 の声は放射線治療の場合と変わらず，治療期間 は放射線よりもはるかに短い。

大切なことは病変の深さの判断で, 以下のよ うにする。

(1)ビデオストロボスコピーで, 病変部に多少 の振動が認められ，隣接する健常部に粘膜波動 が認められる場合には, 病変は浅い。

(2)手術用顕微鏡下の触診で, 病変部に隣接す る外側の部を軽く押し, 病変部がくるっと回転 するように動けば，浅いと判断する。

(3)粘膜固有層浅層内へ局所麻酔液を注射し, 病変部だけが浮き上がれば，浅いと判断する。 この注射により切除操作も容易になる。

声帯勒帯の表層部まで癌が達している場合に は，患者や家族と相談して放射線か手術かを選 ぶ。手術では声帯靶帯を切除する必要がある(図 2 B)。制御率には差はないが, 声は放射線の方 が少しよく，治療期間は手術の方が短い。

声帯筋の表層部まで癌が入っている場合に

A

B

C

D

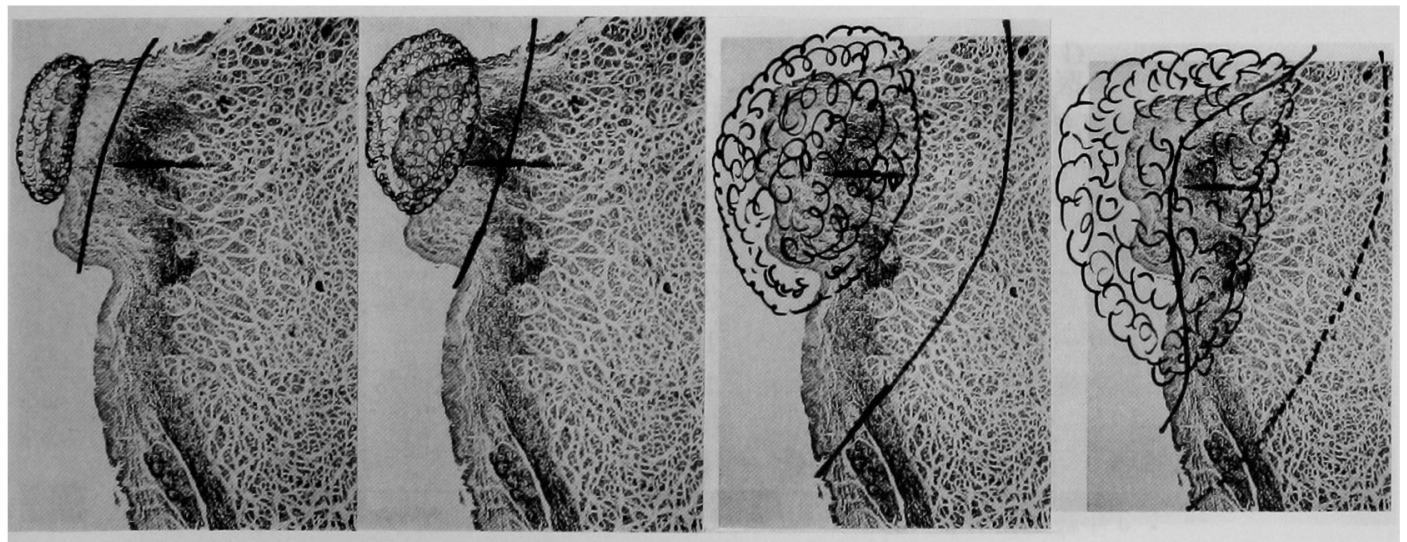

図 2 声門癌 T1 に対する手術（説明は本文中） 
も，患者や家族と相談して治療法を選ぶ。手術 を選ぶと筋を大きく切除せねばならない（図 2 C)。制御率はほほ同じ，声は手術の方が覀い， 治療期間は放射線の方が長い，という条件下で の選択である。

病変が大きい Tlaには, レーザーによる減量 手術と放射線治療をすすめる。減量の要否は, 放射線科医の意見を主にしてチームで決める。 声帯がほほ正常な形になるまで, 病変部を減量 する(図 $2 \mathrm{D}$ )。手術だけで治療すると, 治療期 間は短いが声が悪くなる。それでも構わないか ら短期間での治療を望む患者では, レーザーで 切除する (図 $2 \mathrm{D}$, 点線)。

\section{2 ) 声門癌 T1b}

多くは放射線治療を主体とする治療を選ぶ。 レーザーで減量するかどうかは, 放射線科医の 意見を主に取り入れて決める。手術だけで治療 すると，大多数の症例で声がかなり悪くなる。 前交連の病変を手術すると webができ, 声が異 常に高く，かつ悪くなる。

例外は両声帯に別々に, 固有層浅層内に限局 した浅い病変がある場合で, 前述の声帯勒帯を 保存する手術を, 左右それぞれに行う。また, 声が悪くなっても構わないから, 短期間での治 療を望む患者では、レーザー手術を行う。

3 ）声門癌 T2

チーム医療を始める前には, 喉頭半側切除術 (半切)の方が, 放射線治療よりも制御率が高く, 半切を多く用いていた。チーム医療を始めてか らは, 病変が外向性で, 筋層への浸潤が軽度な 場合には，レーザーによる減量と放射線治療を
行う。早期の T2では, 放射線だけかレーザー手 術だけを用いた例もある。声門下，声門上へ広 く進展している例では喉頭全摘を行うこともあ る。年齢や全身状態も考慮して選ぶ。

4) Tis, T1, T2 の治療成績（表 2）

121 例中 8 例に再発を認めた。

Tis の再発例では，術中のビデオを検討する と病変の取り残しがあり, 再発時には浸潤癌で, レーザーによる減量と放射線で制御されてい る。Tla の再発例は喉頭半切で制御された。T1 $\mathrm{b}$ の再発 4 例中, 1 例はレーザー手術, 2 例は知 頭半切， 1 例は喉頭全摘によって制御されてい る。T2 の再発 2 例は喉頭全摘によって非担癌, 生存している。

原病死はなく他病死が 9 例ある。

5) 声門癌 T3, T4

通常喉頭全摘を行う。初期の T3では半切を 行うこともある。術後照射は, 摘出標本の大切 片標本についての病理組織所見, 転移リンパ節 の状態を検討して決める。

\section{2. 声門上癌}

1）声門上癌 T1

放射癌, レーザー手術, レーザーによる減量 手術と放射線の併用を，症例ごとに選択する。 放射線治療中は，毎週の共診で放射線を続ける か, 減量手術を組み込むか, 手術に切り替える か，を検討する。制御率 $100 \%$ を最終目標として いる。

2 ）声門上癌 T2

チーム医療を始める前には，声門上水平部分

表 2 チーム医療による声門癌 Tis，T1，T2 の治療成績一Kaplan-Meier 法による 3 年制御率

\begin{tabular}{|c|c|c|c|c|c|c|c|c|}
\hline & \multicolumn{2}{|r|}{ Tis } & \multicolumn{2}{|c|}{ Tla } & \multicolumn{2}{|c|}{$\mathrm{T} 1 \mathrm{~b}$} & \multicolumn{2}{|r|}{$\mathrm{T} 2$} \\
\hline & $\mathrm{n}$ & 制御率 & $\mathrm{n}$ & 制御率 & $\mathrm{n}$ & 制御率 & $\mathrm{n}$ & 制御率 \\
\hline 放射線 & 0 & & 25 & $95 \%$ & 33 & $88 \%$ & 8 & $100 \%$ \\
\hline マイクロサージャリ & 1 & $0 \%$ & 10 & $100 \%$ & 2 & - & 1 & - \\
\hline 減量と放射線 & 0 & & 14 & $100 \%$ & 10 & $100 \%$ & 11 & $88 \%$ \\
\hline 喉頭半切 & 0 & & 0 & & 0 & & 4 & $75 \%$ \\
\hline 喉頭全摘 & 0 & & 0 & & 0 & & 2 & - \\
\hline
\end{tabular}

- : 3 年経過例がない。

再発 8 (Tis, $1 ; \mathrm{T} 1 \mathrm{a}, 1 ; \mathrm{T} 1 \mathrm{~b}, 4 ; \mathrm{T} 2,2$ ), 原病死 0 , 他病死 9 。 
表 3 チーム医療による声門上癌 T1, T2 の治療成 績一Kaplan-Meier 法による 3 年制御率

\begin{tabular}{llllll}
\hline & \multicolumn{2}{c}{$\mathrm{T} 1$} & & \multicolumn{2}{c}{$\mathrm{T} 2$} \\
\cline { 2 - 3 } \cline { 5 - 6 } & $\mathrm{n}$ & 制御率 & & $\mathrm{n}$ & 制御率 \\
\hline 放射線 & 4 & $100 \%$ & & 3 & $67 \%$ \\
隇量と放射線 & 2 & $100 \%$ & & 8 & $86 \%$ \\
声門上水平部切 & 0 & & & 3 & $100 \%$ \\
$\quad$ と術後照射 & & & & & \\
喉頭全摘 & 0 & & & 1 & - \\
\hline
\end{tabular}

一：3 年経過例がない。

再発 2 (T2), 原病死 1 (遠隔転移), 他病死 3 。

切除（水平部切）が多かったが，チーム医療を 始めてからは, 放射線か減量手術と放射線の併 用がふえた。 $\mathrm{N}+$ 例では頸部郭清も行う。 $\mathrm{N}$ 一例 では, 通常予防的頸部郭清をしていない。Nに ついては触診だけでなく, CT や MRI も用いて 判定する。

3 ) T1, T2 の治療成績（表 3 ）

21例中再発は T2で 2 例におこり，1 例はレ ーザー手術，1例は喉頭全摘によって制御され ている。原病死の 1 例は $\mathrm{T} 2 \mathrm{~N} 2$ の例で, 局所と 頸部に再発はないが, 肺と骨への遠隔転移で死 亡した。

\section{4）声門上癌 T3, T4}

ほとんどの例で喉頭全摘を選ぶ。稀に水平部 切と術後照射を選ぶことがある。舌根部に入っ ていて声帯は正常な T4, 声門部に表在性の浸 潤がある T3 の場合である。頸部郭清はN の如 何にかかわらず行う。

\section{3.チーム医療による喉頭癌の治療成績}

症例は声門癌 146 (Tis 1, T1 95, T2 26, T3 10, T4 14), 声門上癌 41 ( T1 6, T2 15, T3 13, T4 7), 計187例である。初治療による原発巣 5 年制御率は $93.3 \%, 5$ 年生存率は全症例で 82.7 \%, 他病死14例を打ち切りとすると $96.7 \%$ で る。原病死は 4 例でリンパ節死 1 , 遠隔転移死 2 , 慢性腎炎の悪化による合併症死が 1 例であ る。

\section{IV．下咽頭癌に対するチーム医療}

\section{Stage III, IV}

症例の多くは Stage III，IVである。まず喉頭 咽頭頸部食道摘出 (喉咽食摘) と, 両側頸部お よび気管傍リンパ節郭清, 甲状腺全摘を行い, 遊離空腸で一期的に再建する。

手術では，通常気管切開を行い，気管孔から 挿管して全身麻酔を施す。耳鼻咽喉科医が病変 を切除する。頸部郭清では, 後で行う血管吻合 に備えて外頸静脈, 頸横動脈を保存する。内頸 静脈は腫瘍の摘出を妨げない限り保存する。喉 頭・下咽頭 - 頸部食道は, 肉眼的に上 $2.5 \mathrm{~cm}$ 以 上,下 $2 \mathrm{~cm}$ 以上の margin をつけて摘出する。 消化器外科が開腹し, 空腸を吻合用血管をつ けて取り出す。空腸を採取している間に, 形成 外科が, 頸部の吻合用の血管をトリミングする。 遊離空腸を外科と耳鼻咽喉科が, 咽頭と食道に 吻合する。咽頭側, 食道側ともに端側吻合とす る。血管吻合は形成外科が行う。お腹は外科が, 頸部は耳鼻咽喉科が閉じる。手術時間は約11時 間である。

A B

C

$\mathrm{D}$

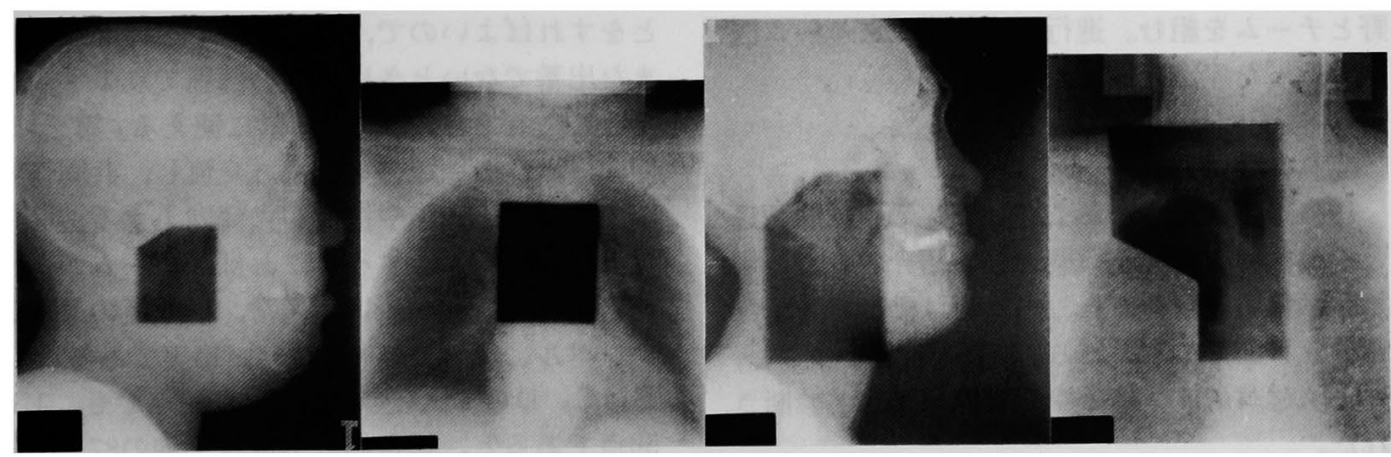

図 3 下咽頭癌に対する術後照射野(説明は本文中) 
術後は耳鼻咽喉科と形成外科とが頸部の創 を，外科が腹部の創を処置する。10日ないし 2 週後から経口食をとらせる。

原則としてルビエールのリンパ節（図 $3 \mathrm{~A}$ ) と上縦隔 (図 $3 \mathrm{~B}$ ) に, それぞれ約 $50 \mathrm{~Gy}$ の術後 照射を行う。術後照射は通常術後約 3 週で始め る。摘出標本の病理組織学的検査で margin が 不十分の場合には, その部分も照射する。Margin が不十分な咽頭側をルビエール・リンパ節 と含めた照射野を図 $3 \mathrm{C}$ に示す。頸部リンパ節 に被膜外浸潤があれば, 化学療法（シスプラチ ンとペプレオまたは $5 \mathrm{FU}$ )を行う。さらに, 被 膜外浸潤のあった部位にも術後照射を行う（図 $3 \mathrm{D})$ 。

チーム医療による32例の 5 年生存率は 54.4 \%, 他病死を打ち切りとすると $67.5 \%$ あるる。 死因はリンパ節再発 5 例, 遠隔転移 3 例, 他病 死 3 例である。

\section{2. 原発巣が小さいまたは浅い場合}

原発巣にはレーザーによる減量手術と放射 線, 頸部には頸部郭清術を行う。リンパ節に転 移があれば, ルビエール・リンパ節と上縦隔に 照射する。被膜外浸潤があるときには, 化学療 法と術後照射も加える。治療の対象は慎重に選 んでいる。始めたのは最近で症例数は 5 例, ま だ遠隔成績は出せない。原発巣は現在のところ 制御されている。

\section{V . 甲状腺に対するチーム医療}

リンパ腫と末分化癌については放射線科, 内 分泌内科, 血液内科とチームを組む。進行した 分化癌では, 進展範囲に応じて, 必要な専門分 野とチームを組む。進行した乳頭癌にチーム医 療を行った症例を示す。

\section{症例 KK，57歳女}

1994年 4 月血痰がおこり, 某院で甲状腺腫瘍 とその気管内進展を指摘されて紹介された。甲 状腺右葉に腫瘤をふれ, 右声帯は動かず, 下哚 頸リンパ節を 1 個ふれる。気管は腫瘍で狭窄し, 呼吸困難がある。組織検査で乳頭腺癌と診断さ れた。

胸部外科, 麻酔科とチームを組み, 次の方針
で治療した。まず jet ventilationによる全麻下 に, 気管内の腫場を電気凝固と YAG レーザー で除去する，次に経口挿管での全麻下に頸部を 手術する。甲状腺全摘, 気管の合併切除, 右頸 部郭清, 両気管傍リンパ節郭清を行い, 気管は 端々吻合する。

7 月 7 日に手術した。気管の合併切除に際し ては，気管を左寄りで開いて腫瘍を明視下にお き，まず下方で気管を切断した。経口插管チュ ーブは, 上方の切断端の上まで引き上げ抜去し ていない。下方の断端から, 別の J チューブを 入れて全麻を維持した。気管の一部と右反回神 経を含めて病変を切除した後, 気管の端々吻合 を行った。吻合に際し，Jチューブを入れてお く隙間がなくなったところで, 細いビニールチ ューブと入れ替え, jet ventilation下に麻酔を 続けた。端々吻合後, 麻酔は再び経口插管によ つて維持した。

術後 5 日から経口食を開始, 当初は誤嚥もあ ったが，睘下訓練によって改善し順調に経過し た。術後 1 年 3 力月再発なく生存している。

\section{VI. ま と め}

チーム医療で全く新しい診断法や治療法が, 生まれたわけではない。基本的には，多くの施 設で似たようなことが行われており，私たちも 以前から用いていた技術を使っている。しかし， チーム医療にはいくつかの利点がある。

第一に, 一人一人の患者に対して, その施設 が行うことのできる最高の医療を提供できる。 したがって治療成績も向上する。似たようなこ とをしていても内容が違う。第二に, 構成員は 仕事が快適にできる。それぞれが得意とするこ とをすればよいので, 無理をする必要がない。 また出番でないときは, 別の部屋で別の手術を することもでき，時間を有効に使える。第三に， 構成員は他の領域の専門家と交流し, 共同作業 をするので, 知識や技術が大変向上する。

チーム医療で心すべきことは，チームが行う 仕事の総合的レベルは, 通常, 構成員の最も低 いレペルになるという，厳しい事実である。A， $\mathrm{B}, \mathrm{C}, \mathrm{D}$ の 4 人のう 3 人が 100 点でも, 1 人 50 点であると, 総合的レベルは平均の87.5では なくて, 50点になる。全員が 100 点で初めて, 総 
合的な結果も, 100点になるのである。したがっ て構成員は, 自分の専門領域で日進月歩の医療 の最高レベルを絶えず切り開き, 維持する必要 がある。

下記のチームの皆さんに心から感謝する。

早㴊尚文, 小島和行 (放射線科): 田井良明, 井上要二郎, 清川兼輔 (形成外科) ; 藤田博正 (第
一外科); 森一功, 坂口伸治 (耳鼻咽喉科); 吉田哲二, 島村 易, 松井正典(聖マリア病院)。

講演の機会と栄覓をお与え下さった岩田重信会長 に，心から御礼申し上げる。

本研究の一部は厚生省がん克服戦略研究事業（海 老原班, 機能を温存する外科療法に関する研究) の 援助を受けた。 